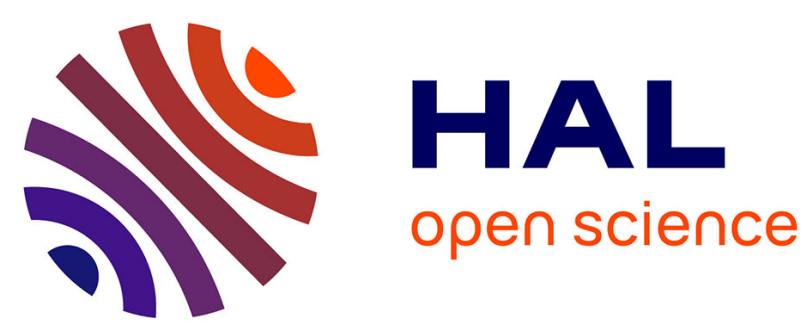

\title{
Sizing and Control of Onboard Multisource Power System for Electric Vehicle
}

\author{
Jamila Snoussi, Seifeddine Ben Elghali, Mohamed Faouzi Mimouni
}

\section{To cite this version:}

Jamila Snoussi, Seifeddine Ben Elghali, Mohamed Faouzi Mimouni. Sizing and Control of Onboard Multisource Power System for Electric Vehicle. 2019 19th International Conference on Sciences and Techniques of Automatic Control and Computer Engineering (STA), Mar 2019, Sousse, France. pp.347-352, 10.1109/STA.2019.8717231 . hal-02390263

\section{HAL Id: hal-02390263 https://hal-amu.archives-ouvertes.fr/hal-02390263}

Submitted on 20 May 2020

HAL is a multi-disciplinary open access archive for the deposit and dissemination of scientific research documents, whether they are published or not. The documents may come from teaching and research institutions in France or abroad, or from public or private research centers.
L'archive ouverte pluridisciplinaire HAL, est destinée au dépôt et à la diffusion de documents scientifiques de niveau recherche, publiés ou non, émanant des établissements d'enseignement et de recherche français ou étrangers, des laboratoires publics ou privés. 


\section{Sizing and Control of Onboard Multisource Power System for Electric Vehicle}

\author{
$1^{\text {st }}$ Jamila Snoussi \\ LAS2E \\ National Engineering School of Monastir \\ Monastir, Tunisia \\ snoussijamila@yahoo.fr
}

\author{
$2^{\text {nd }}$ Seifeddine Ben Elghali \\ LIS \\ Aix Marseille Unversity AMU \\ Marseille, France \\ seifeddine.benelghali@lis-lab.fr
}

\author{
$3^{\text {rd }}$ Mohamed Faouzi Mimouni \\ $L A S 2 E$ \\ National Engineering School of Monastir \\ Monastir, Tunisia \\ mfaouzi.mimouni@enim.rnu.tn
}

\begin{abstract}
This paper deals with the sizing and control of a fuel cell based hybrid power supply used in vehicular applications. The system consists of a fuel cell, a battery and a pack of ultracapacitors connected to three DC-DC converters. The proposed approach takes into account dynamic constraints and energetic capacity limits of the power sources by considering a filtering based energy management strategy and energetic characteristics of the used technologies. The sizing solutions are computed for two different driving cycles and then the systems are modeled and simulated using MATLAB/SimPowerSystems. The obtained results are given and discussed.

Index Terms-Fuel cell hybrid vehicle, electric storage systems, sizing, energy management strategy.
\end{abstract}

\section{INTRODUCTION}

Fuel Cell (FC) electric vehicles are clearly an interesting alternative for clean and efficient propulsion [1]. This technology exploits the benefits of Proton Exchange Fuel Cells (PEMFC) in terms of good autonomy and energy efficiency and the benefits of Electric Storage Systems (ESS) such as Batteries (BAT) and Ultracapacitors (UC) in terms of high dynamics and stability [2].

However, the weight of the hybrid power system including the PEMFC, the hydrogen tank, the storage systems and the power converters presents a significant issue to design commercially viable FC vehicles. Indeed, the weight of the onboard power system can harmfully affect the fuel consumption, the energy efficiency and the autonomy of the vehicle when its components are inaccurately sized. In general, an oversized system could cause an over hydrogen consumption and dynamic performance degradation while an insufficient sizing could give rise to serious problems in meeting the vehicle demand during its missions.

A second important factor influencing the performances of the FC hybrid vehicle is the management of the energy flow within the system [3]. This algorithm is in fact necessary to efficiently share the demanded power between the string components while taking into account their dynamic and energetic constraints.

In fact, the challenging issue with such technology is to design an optimal onbroad power supply which should be able to ensure the vehicle requirement in various driving conditions (acceleration, deceleration...) while meeting automotive mar- ket expectations in terms of mass, autonomy, dynamics and fuel consumption.

Conventionally, the design of hybrid systems is done in a sequential way by going through three basic steps: 1- the definition of the system architecture, 2-the sizing of different components (sources, converters,load, etc.) and 3- the adoption of an energy management strategy [4].

However, this approach can lead to systems oversizing or even to incompatibility between the demand and the sources capacity, since the sizing is done in a random way, without information about the part of mission to be required from each device. Therefore, it would, be more judicious to link the sizing of each source to its own mission by inverting the order of the sizing and the management phases.

This paper proposes a method to size an onboard FC/BAT/UC power source used in electric vehicles by considering a power-separation-based energy management algorithm and energetic characteristics of the sources.

With respect to aforementioned works, the proposed approach lead to efficiently size the system components while taking into account their intrinsic energetic and dynamic limitations. We propose to firstly distribute the mission power between the sources and then to size the elementary cells of each device according to its own mission, which could minimize the overall weight of the system.

The paper is organized as follows: Section 2 illustrates the vehicle powertrain system. Section 3 details the filtering energy management strategy. Section 4 explains the sizing process. Section 5 gives and discusses the obtained simulation results and 6 provides the conclusions.

\section{FUEL CELL BASED POWERTRAIN SYSTEM}

\section{A. Vehicle configuration}

The reference [5] provides a variety of configurations for the electric vehicles. We propose to use a parallel architecture in this work (Fig. 1). This topology offers a good pliability in the sources control. The system is composed of a PEM fuel cell, a lithium battery and a pack of ultracapacitors. The power sources are linked to the traction inverter via three DC-DC converters and can supply together or separately the electric motor. 


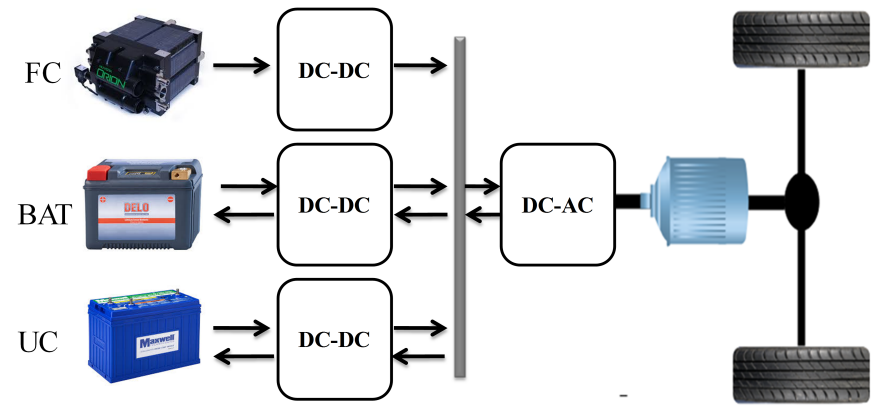

Fig. 1: Vehicle configuration.

\section{B. Source characteristics}

Hydrogen fuel cells are considered as storage systems since it use stored compressed hydrogen to generate electricity [6]. Indeed, ESSs are usually compared through their dynamic and energetic characteristics via specific charts such as the Ragone diagram [7]. This chart illustrates the specific power of the

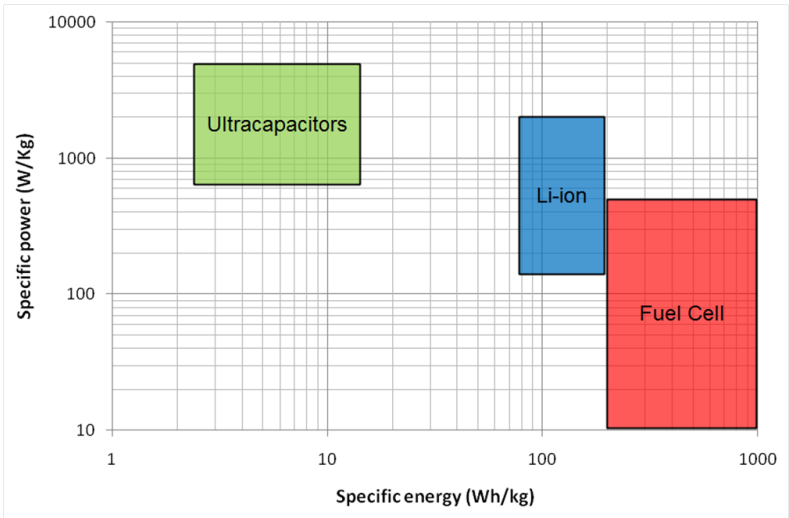

Fig. 2: Ragone diagram

storage device according to its specific energy (fig.2). We note that the FC is characterized by the the higher specific energy. It ensures an excellent autonomy for the vehicle in terms of several hours [8] and has a very low rate of auto discharge. But, its low specific power and long start up time limit notably its performances in high dynamic applications such as vehicles.

Lithium battery presents distinct advantages in comparison with conventional lead acid and nickel models, including high specific energy, low self-discharge rate and wide range of operating temperature [9]. Nevertheless, it is still sensitive to fast and frequent load current variations, which can limit significantly its life cycle .

Supercapacitors, characterized by an excellent power density, a very low energy density and a short charging and discharging time [10], could be able to generate/absorb sudden transients of the load.

\section{Modeling}

1) Fuel cell: To reproduce dynamic characteristics of the PEMFC, an electric equivalent circuit based model is adopted
(Fig. 3) [4].

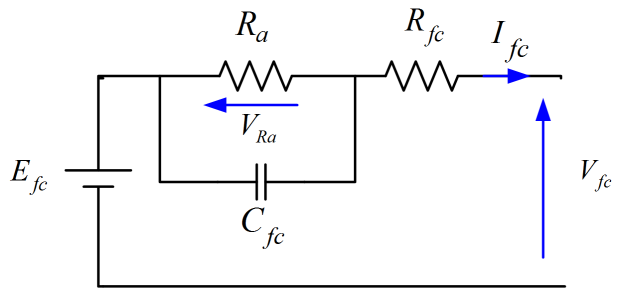

Fig. 3: Fuel cell model

Its mathematical model is given in (1).

$$
\left\{\begin{array}{l}
I_{f c}=\frac{V_{R a}}{R_{a}}+C_{f c} \frac{d V_{R a}}{d t} \\
V_{f c}=E_{f c}-V_{R a}-R_{f c} I_{f c}
\end{array}\right.
$$

Where $I_{f c}, V_{f c}$ are the FC current and voltage respectively. $R_{a}, R_{f c}, C_{f c}$ are the electric circuit parameters.

2) Lithium battery: A new electric model (fig.4) [2] is proposed to simulate the battery in this application. A capacity

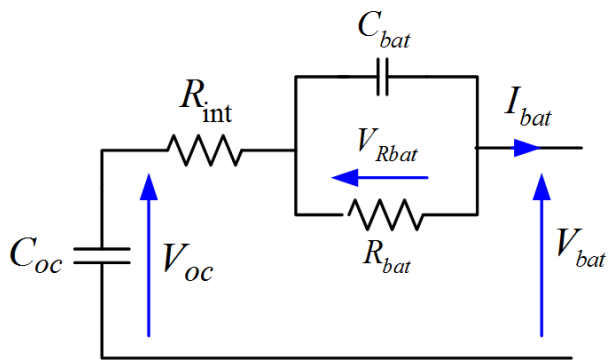

Fig. 4: Battery model

$C_{o c}$ of charge and discharge is used instead of constant voltage source in classic Thevenin circuit. $R_{\text {int }}$ represents the internal resistance of the battery, $R_{b a t} C_{b a t}$ simulates the rest time effect on the battery response time.

Its mathematical model is given in (2)

$$
\left\{\begin{array}{l}
I_{b a t}=-C_{o c} \frac{d V_{o c}}{d t} \\
V_{b a t}=V_{o c}-R_{i n t} I_{b a t}-V_{R b a t} \\
\frac{d V_{R b a t}}{d t}=-\frac{1}{R_{b a t} C_{b a t}} V_{R b a t}+\frac{1}{C_{b a t}} I_{b a t}
\end{array}\right.
$$

3) Ultracapacitors: The model of the ultracapacitors pack is illustrated in fig. 5. Where $R_{u c}, C_{u c 1}$ and $C_{u c 2}=\beta V_{u 1}$ are

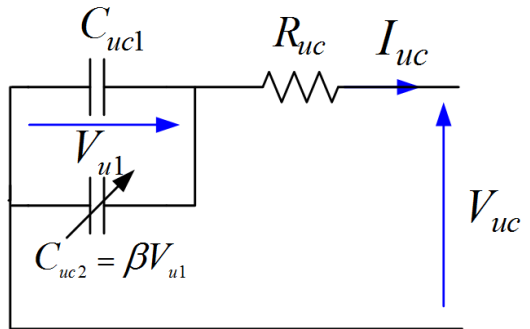

Fig. 5: Ultracapacitor model 
the electric parameters of the circuit. Its mathematical model is provided in (3).

$$
\left\{\begin{array}{l}
I_{u c}=-\left(C_{u c 1}+\beta V_{u 1}\right) \frac{d V_{u 1}}{d t} \\
V_{u c}=V_{u 1}-R_{u c} I_{u c}
\end{array}\right.
$$

4) Drive mission: During missions, the vehicle draws a total power $P_{L}$ from the DC bus. This power is computed as (4):

$$
P_{L}=\frac{\eta_{\text {ond }}}{v_{d c}}\left(0.5 \rho v^{2} S_{f} C_{x}+M_{v e h} g C_{r}+M_{v e h} \frac{d v_{v e h}}{d t}\right) v_{v e h}
$$

Where $\eta_{o n d}, v_{d c}, v_{v e h}, \rho, C_{x}, S_{f}, M_{v e h}, C_{r}$ and $g$ are the inverter efficiency, the DC bus voltage, the drive cycle, the air density, the aerodynamic coefficient, the frontal surface of the vehicle, the mass of the vehicle mass, the rolling coefficient and the gravitational constant respectively.

\section{FREQUENCY-SEPARATION-BASED ENERGY MANAGEMENT STRATEGY}

1) Frequency vision of system: By exploiting the characteristics of the Ragone chart, we can develop a frequency vision for the power sources basing on the notion of specific frequency $f_{c}[11]$, defined as follow:

$$
f_{c}[H z]=\frac{\rho^{P}[W / k g]}{\rho^{E}[J / k g]}
$$

Where $\rho^{P}$ is the power density of the device and $\rho^{E}$ is its energy density. Using (5), the elements of the chart can be reported in a frequency plane defining the frequency ranges allowed by each element. Fuel cells are the lowest element in the system and can cover the lowest frequency range of the demand. The batteries have a faster dynamic and can cover the intermediate frequencies and supercapacitors present the fastest element and can cover the highest frequencies of the demand.

2) Frequency separation strategy: The energy management strategy proposed is based on the load power decomposition [12]. Indeed, we decompose the total power into three compo-

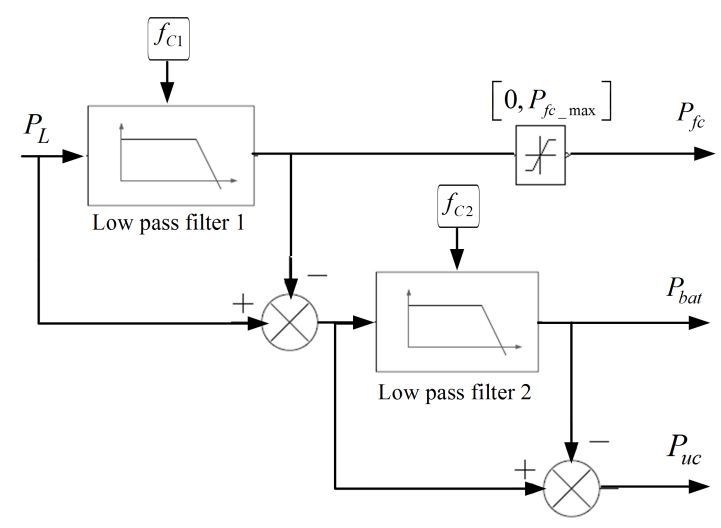

Fig. 6: Frequency energy management

nents with three frequency ranges (fig.6). The first component $P_{\text {pac }}$, which is the lowest one, will be used to size the PEMFC.
The second component $P_{b a t}$ will be used to size the battery and the latest $P_{u c}$, which is the faster component, will be used to size the ultracapacitors. To this end, we used two low pass filters with two different cut-off frequencies $f_{c 1}$ and $f_{c 2}$.

\section{SizING OF THE FC/BAT/UC HYBRID SOURCE}

\section{A. Fuel cell sizing}

The PEMFC is sized using the FC power evolution $P_{f c}$ [13]. The number of its cells $N_{f c}$ is determined as (6):

$$
N_{f c}=\frac{\max \left(P_{f c}\right)}{P_{f c}^{0}}
$$

Where $P_{f c}^{0}$ is the FC cell power.

The mass of the fuel cell $M_{f c}$ is the sum of the weight of the stack $M_{s t}$, the weight of the hydrogen $M_{H 2}$ and the weight of the hydrogen tanks $M_{t a}$ :

$$
M_{f c}=M_{s t}+M_{H 2}+M_{t a}
$$

The weight of the stack is defined by:

$$
M_{s t}=N_{f c} m_{f c}^{0}
$$

Where $m_{f c}^{0}$ is the FC cell weight.

The hydrogen to be consumed in a duration $\Delta t$ is defined as (9):

$$
M_{H_{2}}=m_{H_{2}} \dot{n}_{H_{2}} \Delta t
$$

Where $\dot{n}_{H_{2}}=\frac{N_{f c} I_{f c}^{0}}{2 F}$ is the molar flow rate of the hydrogen, $I_{f c}^{0}$ is the FC cell current, $m_{H 2}$ is the molar mass of $H_{2}$ and $F$ is the Faradays constant.

To get the wight of the hydrogen tanks we should calculate their number $N_{t a}$ as (10):

$$
N_{t a}=\frac{M_{H_{2}}}{m_{v o l}\left(H_{2}\right) V_{t a}}
$$

Where $M_{H 2}$ is the weight of hydrogen, $m_{v o l}\left(H_{2}\right)$ is its density and $V_{t a}$ is the volume of the tank. The total mass of the obtained tanks is calculated using (11).

$$
M_{t a}=N_{t a} M_{t a}^{0}
$$

Where $M_{t a}^{0}$ is the mass of a single tank.

\section{B. Battery sizing}

The number of battery cells $N_{b a t}$ is calculated basing on the battery power and energy missions. The sized battery should:

- Generate/recover the maximum of the required/regenerated power $P_{b a t}^{\max }$ provided by the energy management algorithm.

- Provide/recover the totality of the required/regenerated energy.

The battery cells number $N_{b a t}$ is given as (12):

$$
N_{b a t}=\max \left(\frac{E_{b a t}^{\max }-E_{b a t}^{\min }}{D O D_{b a t} \cdot E_{b a t}^{0}}, \frac{\max \left|P_{b a t}(t)\right|}{P_{b a t}^{0}}\right)
$$

Where $P_{b a t}^{0}$ is the battery cell power, $E_{b a t}^{0}$ is the energy cell energy, $D O D_{b a t}$ is the battery Depth Of Discharge (DOD) 
and $E_{b a t}^{\text {max }}, E_{b a t}^{\text {min }}$ are determined from the battery energy evolution, respectively.

The battery weight is defined in (13):

$$
M_{b a t}=N_{b a t} m_{b a t}^{0}
$$

Where $m_{b a t}^{0}$ is the battery cell mass.

\section{Ultracapacitor sizing}

Similarly to the BAT, the number of ultracapacitors $N_{u c}$ should satisfy the power and energy constraints as follows:

$$
N_{u c}=\max \left(\frac{E_{u c}^{\max }-E_{u c}^{\min }}{D O D_{u c} \cdot E_{u c}^{0}}, \frac{\max \left|P_{u c}(t)\right|}{P_{u c}^{0}}\right)
$$

Where $D O D_{u c}$ is the ultracapacitor depth of discharge. $E_{u c}^{0}$ and $P_{u c}^{0}$ are the maximal ultracapacitor energy and the maximal ultracapacitor power, respectively. $E_{u c}^{\max }, E_{u c}^{\min }$ are determined from the UC energy evolution

The weight of the ultracapacitors module is calculated according to $N_{u c}$ as follow:

$$
M_{u c}=N_{u c} m_{u c}^{0}
$$

Where $m_{u c}^{0}$ is the mass of the elementary ultracapacitor.

Then the hybrid power source weight $M_{s y s}$ is calculated as (16):

$$
M_{s y s}=M_{f c}+M_{b a t}+M_{u c}
$$

\section{SIZING RESULTS}

The sources technologies used in this application are the Toyota Mirai FC stack [15], the lithium iron phosphate $\left(\mathrm{LiFePO}_{4}\right) 12 \mathrm{~V} / 40 \mathrm{Ah}$ battery and the $2.7 \mathrm{~V} / 3000 \mathrm{~F}$ Boostcap ultracapacitors. Their technical characteristics are illustrated in TABLE I.

TABLE I: Characteristics of the sources

\begin{tabular}{|c|c|c|c|}
\hline & PEMFC & BAT & UC \\
\hline \hline Maximal cell power & $300 W$ & $384 W$ & $3.0166 k W$ \\
\hline Maximal cell energy & - & $128 W h$ & $3.0375 W h$ \\
\hline Cell weight & $150 g$ & $1500 g$ & $500 g$ \\
\hline Tank weight & $85 k g$ & - & - \\
\hline Tank volume & $100 \mathrm{~L}$ & - & - \\
\hline
\end{tabular}

The sizing is computed using MATLAB/Simulink for two different driving cycles. The first one is the New European Driving Cycle (NEDC), it represents a typical usage of the vehicle in Europe including four repetitive urban driving cycles (ECE-15) and one Extra-Urban Driving Cycle (EUDC), Fig. 7a. The second one is the US Federal Test Procedure cycle (US FTP-72), also called the Urban Dynamometer Driving Schedule (UDDS) and simulates an urban driving mission with more frequent stops, Fig. 7b.

The sources and the overall system obtained weights are given in TABLE II.

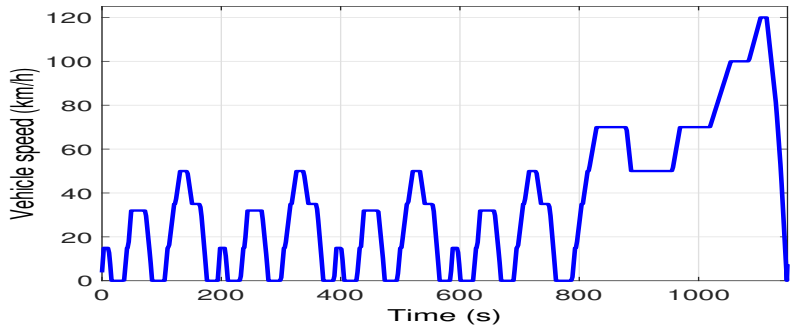

(a)

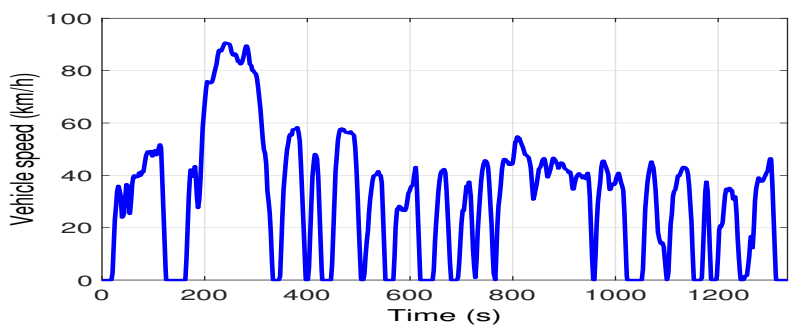

(b)

Fig. 7: Vehicle driving cycles: (a) NEDC, (b) UDDS.

TABLE II: Sizing results

\begin{tabular}{|c||c|c|}
\hline & NEDC & UDDS \\
\hline \hline$M_{\text {sys }}$ & $296.8 \mathrm{~kg}$ & $223 \mathrm{~kg}$ \\
\hline$M_{f c}$ & $85.8 \mathrm{~kg}$ & $85.47 \mathrm{~kg}$ \\
\hline$M_{b a t}$ & $148.8 \mathrm{~kg}$ & $96.42 \mathrm{~kg}$ \\
\hline$M_{u c}$ & $62.34 \mathrm{~kg}$ & $41.36 \mathrm{~kg}$ \\
\hline$N_{f c}$ & 55 & 34 \\
\hline$N_{\text {bat }}$ & 99 & 64 \\
\hline$N_{u c}$ & 122 & 81 \\
\hline
\end{tabular}

To validate the relevance of the proposed approach, the obtained systems are modeled and simulated under Matlab/SimPowerSystems using the parameters of TABLE II.

Fig. 8 and Fig. 9 illustrate the electric powers and energies obtained for the NEDC and the UDDS.

As can be noted from Fig. 8a and Fig. 9a, the missions requirements are ensured by the sized hybrid power supply. The sum of the generated power $\left(P_{f c}+P_{b a t}+P_{u c}\right)$ matches the totality of the the demanded power $P_{L}$. Then, the sources are efficiently sized with respect to the missions demand.

Figures $8 \mathrm{~b}, 8 \mathrm{c}, 9 \mathrm{~b}$ and $9 \mathrm{c}$ show that the total load power and energy are well shared between the sources. Frequency and energetic constraints of the multisource system are respected under the NEDC and the UDDS: the FC ensures the lower dynamic component and provides the highest part of the demanded energy. The battery provides the intermediate frequency component and supplies high energy and the supercapacitors cover the fast fluctuated part of the power with a very low amount of energy. The relevance of the filtering management algorithm is then validated. 


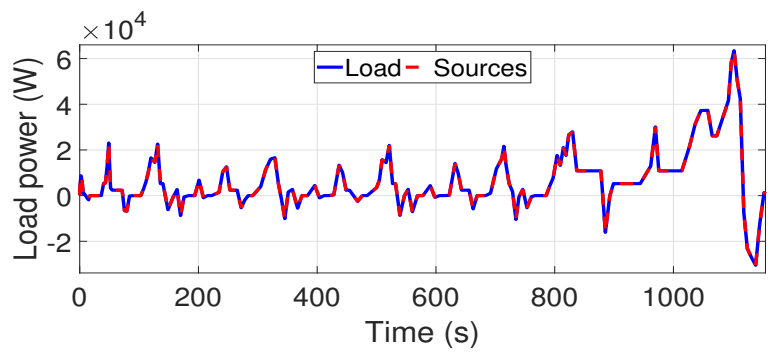

(a)

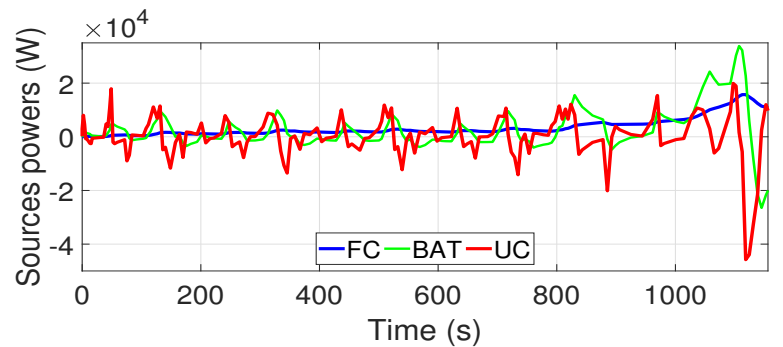

(b)

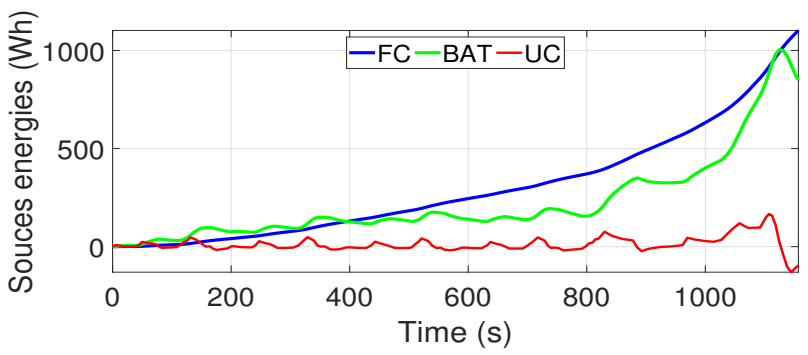

(c)

Fig. 8: Simulation results obtained for the NEDC : (a) Load power vs. delivered power (b) Sources powers (c) Sources energies

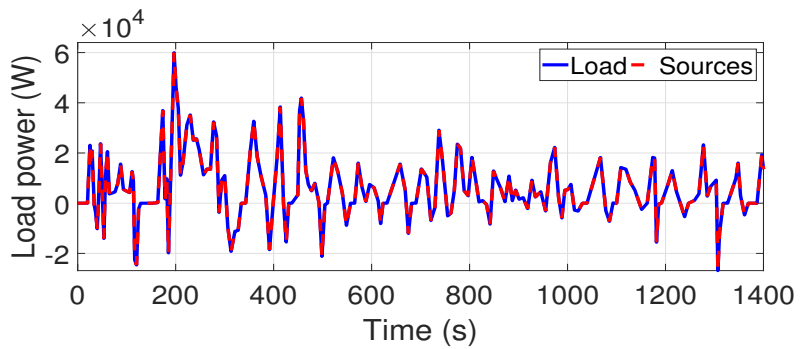

(a)

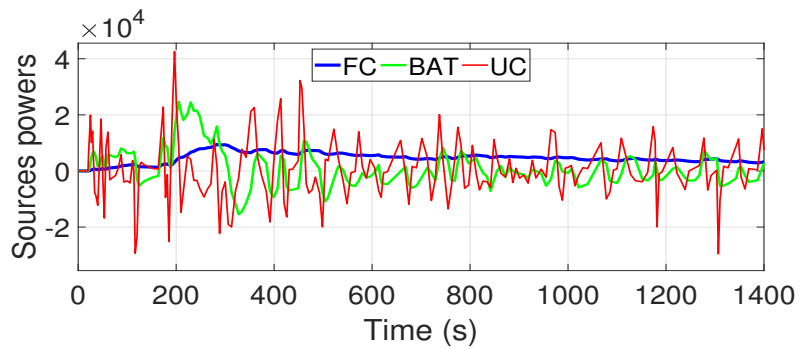

(b)

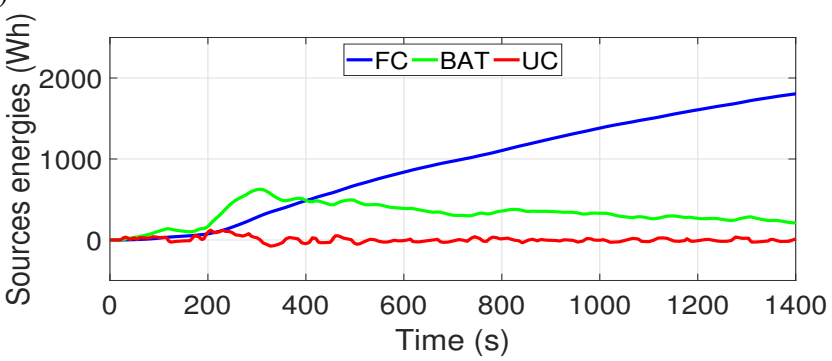

(c)

Fig. 9: Simulation results obtained for the UDDS : (a) Load power vs. delevered power (b) Sources powers (c) Sources energies

Moreover, in order to validate the sizing with respect to the ESS storage capacities, we simulated the evolution of the depths of discharge for the battery (Fig. 10a) and the ultracapacitors (Fig. 10b) over the two driving cycles.

The limits $D O D_{b a t}=0.6$ and $D O D_{u c}=0.8$ fixed in this application are respected for the two storage devices. Then, the system sizing is in good agreement with the energetic demand.

\section{CONCLUSION}

This paper treated the issues of onboard hybrid sources sizing and energy management. The hybrid system includes a fuel cell as main source associated to a battery and a bank of ultracapacitors as hybrid storage device. The developed method aims to ensure the vehicle mission requirement while respecting energetic and dynamic constraints of each technology.

A frequency separation based energy management strategy is adopted. This algorithm is used to size the system sources according to their mission parts and allowed to exploit the benefits of ultracapacitors as a peak power device and the fuel cell and the battery as excellent energy units.

Simulation results obtained for various driving cycles vali- 


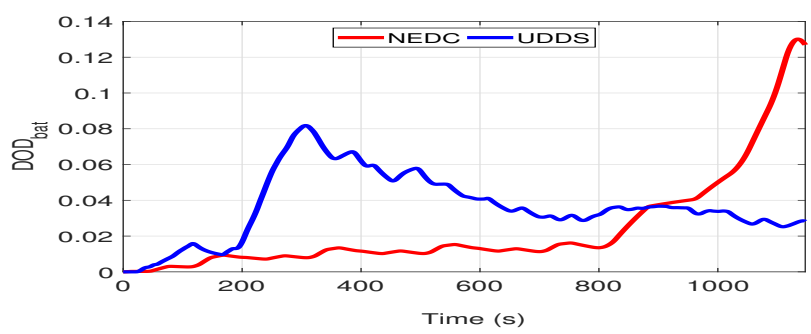

(a)

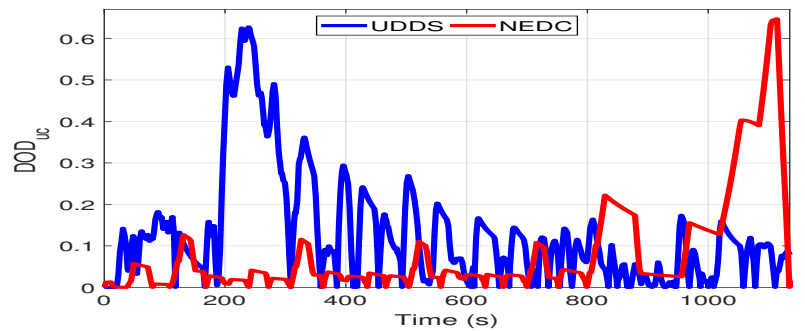

(b)

Fig. 10: Depth of discharge evolutions : (a) NEDC (b) UDDS

dated the sizing approach. The systems are well-sized in terms of dynamic and energetic performances.

\section{REFERENCES}

[1] O. Erdinc and M. Uzunoglu, Recent trends in pem fuel cell-powered hybrid systems: Investigation of application areas, design architectures and energy management approaches". Renewable and Sustainable Energy Reviews, vol. 14, no. 9, pp. 2874 2884, 2010.

[2] J.Snoussi, S. Ben Elghali, M. Benbouzid and M.F Mimouni. "AutoAdaptive Filtering-Based Energy Management Strategy for Fuel Cell Hybrid Electric Vehicles". Energies, vol. 11, no. 8, 2018.

[3] N. Sulaiman, M. Hannan, A. Mohamed, E. Majlan, and W. W. Daud,A review on energy management system for fuel cell hybrid electricvehicle: Issues and challenges, Renewable and Sustainable EnergyReviews, vol. 52, no. Supplement C, pp. 802814, 2015.

[4] Maker Hattab. Optimisation et gestion dnergie pour un systme hybride: association plie combustible et supercondensateurs. PhD thesis, Universit de technologie Belfort Montbliard, 2008.

[5] T. Zimmermann, P. Keil, M. Hofmann, M.F. Horsche, S. Pichlmaier and A. Jossen, Review of system topologies for hybrid electrical energy storage systems.Journal of Energy Storage, vol.8, pp. 78 90, 2016.

[6] Z. Hu, J. Li, L. Xu, Z. Song, C. Fang, M. Ouyang, G. Dou, and G. Kou,Multi-objective energy management optimization and parameter sizingfor proton exchange membrane hybrid fuel cell vehicles,Energy Conversion and Management, vol. 129, pp. 108121, 2016.

[7] T. Christen and M. W. Carlen, Theory of ragone plots,Journal of Power Sources, vol. 91, no. 2, pp. 210 216, 2000.

[8] L. Vasquez,Fuel Cell Research Trends. Nova Science Publishers, 2007.

[9] M. S. Whittingham, R. F. Savinell, and T. Zawodzinski, Introduction: batteries and fuel cells, 2014.

[10] B. Viswanathan, Chapter 13 - supercapacitors, inEnergy Sources(B. Viswanathan, ed.), pp. 315 328, Amsterdam: Elsevier, 2017.

[11] Akli, C.R. Conception systemique dune Locomotive hybride autonome: Application a la locomotive hybride de demonstration et dinvestigations energetique LhyDIE developpee par La SNCF; INP Toulouse: Toulouse, France, 2008.

[12] J. Snoussi, S. B. Elghali, R. Outbib, and M. F. Mimouni, Sliding mode control for frequency-based energy management strategy of hybrid storage system in vehicular application, in 2016 International Symposium on Power Electronics, Electrical Drives, Automation and Motion (SPEEDAM), Italy, 2016.

[13] Hydrogen and Fuel Cells (Second Edition)(B.Sorensen, ed.), Sustainable World, pp. 14, Boston: Academic Press, second edition ed.,2012.

[14] R. Kotz, M. Bartschi, F. Bchi, R. Gallay, and P. Dietrich, A fuel cell car boosted with supercapacitors, in The 12th International Seminar on Double Layer Capacitors and Similar Energy Storage Devices, vol. 12, December 2002

[15] T. Yoshida and K. Kojima, Toyota mirai fuel cell vehicle and progress toward a future hydrogen society,Electrochem Soc Interface, pp. 4549, 2015. 